\title{
Analyzing Jewish Charity and Its Referential Significance
}

\author{
Yinping Ji \\ Shandong Women's University \\ Ji'nan, China
}

\begin{abstract}
Judaism is the religion which is attaching great importance to laws. Among many laws and statutes, the laws about charity are of great importance. Judaism does not mention too much on dogmas or creeds but pay much attention to daily life practice. Charity plays a great part in the daily life of Jewish people. The characteristics and values of Jewish charity are summarized in this paper and its referential significance for Chinese philanthropy nowadays is analyzed.
\end{abstract}

Keywords_Judaism; charity; Chinese
Philanthropy

\section{INTRODUCTION}

Judaism attaches great importance to laws, and among these many laws and statutes, the laws about charity play a great part in Jewish life. It is said that charity is one of the basic creeds of Jewish people, and it is even the foundation of some other stipulations. Charity means justice, and it is a way to pursue social justice. During the long history, Judaism has establishes its own characteristics on charity, and Jewish people has developed many charity organizations and institutions, which have achieved great influence on Jewish society. Therefore, some referential significance can be concluded for Chinese philanthropy.

\section{CHARITY IN JUDAISM}

In Hebrew, the word Tsedakah equals the English word charity, which means "righteous action". The ideas about Jewish charity are originated from the root word Tsadak, which means "to be just or righteous". In English, we use the words charity or philanthropy to express the beneficent acts such as helping and providing almsgiving to the needed. Both words express individual love to others. The same meaning can also be found in Chinese. In Chinese, charity illustrates the combination of kindness and conscience. Therefore, in Judaism, charity is one of the expressions of justice because Jewish charity is from the root word Tsadak which means justice. Jewish charity illustrates what is justice, and implies that charity is the behavior to show justice.

In Hebrew Bible, Tsedakah means the righteous and just behavior, such as helping and aiding the poor and needy. These behaviors were the ways to achieve the social fairness and equality, and realize justice. There are a lot of laws and statutes dealing with caring about and helping the poor in the Bible, which could be adopted by the Jewish people at that time (Lev19 : 9-10; Deu24 : 20-21; Lev 25 : 2$6)$.The most influential law on helping the poor in the Bible, which has been kept and promoted in the following thousands of years, is tithe. Laws about "the Poor's Tithe" have influenced the Jewish people greatly (Deu14 : 28-29). This is the reason why rabbis regulated one's $1 / 10$ property as the charity donation during Talmudic period. After the second temple was destroyed, some Jewish people gradually formed a new habit in the Diaspora period_— to spend 1/10 income on charity and this habit has been followed by most Jews nowadays.

By the Talmudic period, rabbis began to adopt the word Tsedakah to express charity. Though in the Bible there were many laws and regulations related to charitable deeds, there was no definite 
word to express the meaning of charity until Talmudic period. In the Talmudic period, Rabbis limited the Hebrew word Tsedakah to one aspect of justice, that is to say, providing almsgiving and helping to the poor through money or other material methods. Since then, Tsedakah has been used to express Jewish charity and philanthropy, by means of almsgiving, relieving the poor or treating others kindly. God is just. Therefore, justice is not a choice for mankind but only the responsibility, mission and holy commandment from God. Charity is not only to help the poor, but also the obligation of donators and the rights of receivers. The ways to give charity to the poor were not only to satisfy their living needs through personal almsgiving or organized donation by Jewish communities, but also to comfort, care for and show sympathy to them.

\section{CHINESE CHARITY INFLUENCED BY CONFUCIANISM}

Like Jewish people with the long history, the Chinese people also have the charity ideas such as supporting the weak and helping the poor from ancient time. Different from the charity in Judaism originated from God, charity in Chinese tradition is based on the kindness and conscience of human nature. Almsgiving is free behaviors, and is the generous donations and aid from one person to other people. Generally speaking, charity is related to generosity. And basically speaking, charity is the manifestation of free will, therefore, whether helping the needy or not depends on the personal decision and feelings.

Confucianism has great influence on Chinese culture, so on Chinese charity. The ideas on humanity in Confucianism have a great influence on the construction of social morality and charity practice. Government should be the main providers of social welfare, and the money and materials for charity were also mainly raised by government. This idea can be concluded in Lunyu, Analects of Confucius. Once $\mathrm{Zi} \mathrm{Lu}$, the student of Confucius, wanted to provide almsgiving, but Confucius stopped him, and said that individual charity would show the irresponsibility of the government. Under the control of state and government, there have been three other charity systems and organizations in Chinese history. The first is the clan charity system which mainly provided almsgiving to the members of the same clan. The second is the religious charity organizations, mainly referring to Buddhism. The third is the philanthropy organizations organized by common people.

There are two reasons why these philanthropy organizations in China developed so slowly. Firstly, charity is hindered by some ideas in Confucianism, which holds the point of view that individual charity activities prove the government's irresponsibility to its people. In Confucianism tradition, almsgiving should be the responsibility of the state and government. Therefore, the main part of the participation in charity was limited to the smallest scope. Common people seldom had chance to take part in philanthropy. This tradition still has influence on Chinese philanthropy nowadays in some way. Secondly, Chinese charity activities were carried out in an inside and close social system, which was opposite to the open and socialized environment that philanthropy needs. Confucianism emphasizes self-cultivating, unifying families, managing states and stabilizing the world. And in the chain self - family - state, there is no the concept of community or fellowship. And each dynasty firmly controlled the formation of organization or community, so it was difficult to establish a philanthropy organization.

Confucianism focuses on social integrity and state control, and does not approve of or advocate individual participation in philanthropy, so Chinese philanthropy has not developed sufficiently in the past thousands years. Now it has the great opportunity to develop in the new environment, with open, thriving economy and social stabilization. In the past ten years, Chinese philanthropy has contributed a lot in almsgiving, education, protecting environment and medical treatment and so on. However, there are still many problems in Chinese philanthropy, such as, the ability to organize is not high enough and the enthusiasm to participate in philanthropy of common people is low.

\section{REFERENTIAL SigNIFICANCE}

From the discussion on charity in Judaism, we can conclude that Charity is the obligation and duty in Judaism. For Jews, charity is not from 
love or sympathy, but is stemmed from the duty of social justice. It is the request and command to take care of the needed. Therefore, as an impartial and equal mediating part, religions have played a great part in philanthropy. Though religions are not the dominated ideology in China, we can still absorb the useful reference from charity in Judaism.

Firstly, charity must have the primary theoretical foundation, which can dominate the practice and be planted in the hearts of common people. Therefore, for Chinese philanthropy without religious background, it is necessary to absorb the useful elements from the traditional Chinese charity ideas to form the kernel concept of charity, which can support the operation of charity practice. Confucianism, Buddhism and Daoism have great influence on Chinese culture. For Confucianism, loving people is the basis of human nature, and kindness has its ethical order, such as loving family and relatives, then loving the others. For Buddhism, mercy and compassion is its kernel. Doing good and helping the needed are the basic laws of Buddhists. The idea on Karma in Buddhism urges people to be kind and help other people. For Daoism, goodness is the nature of human beings, so charity is the natural tendency of human. Thus, advocating the traditional ideas on charity, from theory to practice and interior accorded with exterior, a new charity construction will be set up.

Secondly, charity should be supervised by laws. To develop philanthropy, there must be regulations and measures matching to it. Until 2012, there have been more than 1900 charity organizations and institutions in China. However, Chinese philanthropy mainly relies on the restrictions from ethics and morality. But only depending on morality is not in effect, charity needs laws to protect its operation. Therefore, it is more important and necessary to make specific regulations to guide charity practice. Also charity theories and regulations will lose their function if there is no actual charity practice.

Thirdly, philanthropy organizations need establishing and improving. The exchanging between philanthropy organizations and common people is not sufficient, so the organizations lack in social trust. Also the number of philanthropy organizations is very small, and the donation from common people is too little. So comparing with some countries, there is a long way to run for Chinese philanthropy. The charity organizations need be open to the public, so the citizens can have trust in charity. Therefore, the enthusiasm to participate in philanthropy of common people must be enhanced and strengthened. At the same time, philanthropy organizations must do social public propaganda better and improve the donation system.

Lastly, each person should have the responsibility and consciousness to participate in philanthropy. Philanthropy is not the cause of some wealthy people, nor the undertaking of the government or philanthropy organizations. It is the obligation of every one. In USA, donation from individual is more than $75 \%$, but in China, personal donation is less than $20 \%$ and most donations are from corporations and enterprises. It is necessary to inject the inner energy and vigor to the concept of charity through absorbing the useful elements in traditional Chinese culture. Therefore, from the balanced, harmonious and good interacting relationship between individual self-interest and others' welfare, the social concept that one should participate in charity as long as he has the ability will come into being. Only when the largest participation in philanthropy comes into being in the whole society, Chinese philanthropy will become a real social systemic project.

\section{REFERENCES}

[1] Himelstein, Shmuel, "Charity in The Oxford Dictionary of the Jewish Religion”. New York: Oxford University Press,1997.

[2] Rabbi Wayne Dosick, "Living Judaism: The Complete Guide to Jewish Belief, Tradition and Practice”.Harper Collins Publisher,1998.

[3] Jacob Neusner, “The Mishnah - a New Translation”. Yale University Press, 1988.

[4] Moshe Weinfeld, "Social Justice in Ancient Israel and in the Ancient Near East". Jerusalem: The Magnes Press, 1995 